\title{
Two types of symbioses between grapsid crabs and a host thalassinidean shrimp
}

\author{
$\operatorname{AUTHOR(S):~}$ \\ Itani, Gyo
}

\section{CITATION:}

Itani, Gyo. Two types of symbioses between grapsid crabs and a host thalassinidean shrimp. PUBLICATIONS OF THE SETO MARINE BIOLOGICAL LABORATORY 2001, 39(2-3): 129-137

\section{ISSUE DATE:}

2001-03-31

URL:

http://hdl.handle.net/2433/176297

RIGHT: 


\title{
Two types of symbioses between grapsid crabs and a host thalassinidean shrimp
}

\author{
GYO ITANI
}

Seto Marine Biological Laboratory, Kyoto University, Shirahama, Wakayama 649-22, Japan

\begin{abstract}
Two species of grapsid crabs, both of the genus Acmaeopleura, were collected from burrows of a thalassinidean shrimp, Upogebia major, in a tidal flat in Japan. One was Acmaeopleura toriumii, co-habiting in the burrows, and the other was an undescribed species, Acmaeopleura sp., clinging to the abdomen of $U$. major. Several specimens of $A$. toriumii were also collected from egg masses of $U$. major. The field experiment and samplings suggested that $A$. toriumii is not a burrowing species and depends on Upogebia burrows. Behavioral observations were also made on crabs of the two species maintained in aquaria together with the shrimp. Acmaeopleura toriumii never clung to U. major and seemed to be an omnivorous feeder. In contrast, Acmaeopleura sp. always clung, and almost specifically to the ventral side of the first and second abdominal segments of the host; moreover this crab sometimes migrated to another host individual. A few days after Acmaeopleura sp. was observed clinging to a shrimp, wounds were observed on the abdomen of the host. This ectosymbiotic crab probably feeds on host tissue. In the field, about $13 \%$ of the collected $U$. major had abdominal wounds attributable to Acmaeopleura sp. Symbiotic relationship between Acmaeopleura sp. and $U$. major will be the first case reported of a crab living ectoparasitically on another decapod.
\end{abstract}

Key words: Acmaeopleura, Brachyura, Upogebia, Thalassinidea, symbiosis, burrow commensal, ectoparasite

\section{Introduction}

The infraorder Thalassinidea comprises decapod crustaceans that are adapted to a burrowing life-style (Poore, 1994). Among thalassinideans, members of the family Upogebiidae are common burrowers in sand and mud in temperate and tropical marine environments around the world. They construct $\mathrm{U}$ - or $\mathrm{Y}$-shaped burrows and create water currents with their rhythmically stroking pleopods. Upogebiids feed mainly on suspended matter strained out of the water current by the setal basket formed by the first and second pereiopods, but are equipped for resuspension feeding and deposit feeding as well (Dworschak, 1987; Griffis and Suchanek, 1991; Nickell and Atkinson, 1995; Coelho et al., 2000).

Although upogebiid shrimps might reduce the abundance of macro-infauna in soft sediment community (Brenchley, 1981; Posey et al., 1991), upogebiid burrows themselves are inhabited by a variety of organisms, such as bivalves, annelids, copepods, shrimps, crabs, and gobiid fishes (Norman, 1891; MacGinitie, 1930, 1935; Grossman, 1979; Rios and Carvacho, 1983). Upogebiid shrimps also serve as hosts for ectosymbiotic animals, such as bivalves and bopyrid isopods (MacGinitie, 1935; Kato and Itani, 1995, 2000)

Brachyuran crabs contain many symbiotic species (Dales, 1957; Sakai, 1976; Weinbauer et al., 1982; Ross, 1983; Števčić et al., 1988; Vandenspiegel et al., 1992). However, crabs known to be symbiotic with other crustaceans have been confined to burrow co-habitants. Some crabs of the family Pinnotheridae live in the burrows of upogebiid and other thalassinidean shrimps in the East Pacific and the West Atlantic (MacGinitie, 1930; 1935; Manning and Felder, 1989).

Grapsid crabs of the genus Acmaeopleura[Subfamily Varuninae] are known only from the Indo-West Pacific region and association of these crabs with upogebiid shrimps has been suggested (Ghani and Tirmizi, 1991; Davie, 1992; Sakai, 2000). Davie (1992) reported that A. toriumii occurred in mud tunnels of either Upogebia major or the echiuroid Ochetostoma erythrogrammon 
from Hong Kong. But ascertaining whether the crabs were definitely associated with either of these potential hosts was difficult because the burrows are highly networked (Davie, 1992). Sakai (2000) also collected $A$. toriumii from tidal flat where a lot of Upogebia yokoyai are distributed but was not able to determine where the crabs lived. Ghani and Tirmizi (1991) reported from the northern Arabian Sea that two female individuals of Acmaeopleura balssi were collected attached to the bases of the thoracic appendages of Upogebia quddusiae, though the identity of these specimens was doubted by Davie (1992) because the male sub-orbital crest, a diagnostic feature of Acmaeopleura crabs, was not mentioned.

In the course of my studies on the symbiotic animals with thalassinidean shrimps, two species of Acmaeopleura were collected from burrows of Upogebia major (De Haan). One was Acmaeopleura toriumii Takeda, and the other was an undescribed species, which was distinctly different from other species of this genus in several morphological characters of carapace and male suborbital crest (Itani, in preparation). I refer to this species as Acmaeopleura sp. in this paper. I will describe two different styles of symbioses adopted by the two Acmaeopleura crabs and will discuss inhabitable space created by Upogebia shrimps. I will use the term "symbiotic" literally in the sense of "living together" in this paper following Ross (1983).

\section{Materials and Methods}

\section{Field collection}

The two species of Acmaeopleura crabs were collected in a tidal mud flat in an estuary at Aio-

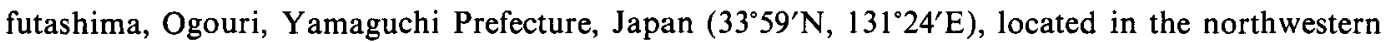
part of the Seto Inland Sea. Sampling was conducted from September 1994 to November 1995, roughly bimonthly. During ebb tide, substrate mud with abundant burrows of Upogebia was scooped up with a shovel to a depth of $50 \mathrm{~cm}$ and sieved. Sometimes the organisms in Upogebia burrows were sucked up with a suction pump similar to that described by Manning (1975).

\section{Observation in aquaria}

In the laboratory, the collected crabs and Upogebia major were kept in flow-through seawater tanks with mud and gravel at the bottom. At the beginning, each tank contained one or two individuals of Acmaeopleura sp., about 15 of Acmaeopleura toriumii, and about five of $U$. major. Pieces of clam or fish were added to the tanks about every three days as possible foods for the crabs and enrichment of mud. Some individuals of $U$. major were kept in U-shaped, transparent, vinyl tubes only slightly larger in diameter than that of the shrimp. Thus, the behavior of the crabs and the host shrimps could be observed under burrow-like conditions. Observations on the behavior of the crabs to the shrimp were made for at least four months; most individuals of both crab species outlived observation period, but most shrimp died within two months. Shrimps were added to the tank after the next sampling had conducted. A total of 10 individuals of Acmaeopleura sp. and more than 50 of Acmaeopleura toriumii were observed. Ovigerous females of the host were not used in this study because they rapidly died in aquaria.

To observe the way Acmaeopleura sp. clings to the host, 10 individuals of Acmaeopleura sp. isolated from their hosts and 20 individuals of Acmaeopleura toriumii were put individually into vinyl tubes containing Upogebia major. Behavior of the crab and the shrimp was observed until the crab either succeeded to cling to the shrimp or failed to cling it and was cast out of the vinyl tube. Observations were made 10 times for each crab.

Field experiment and distribution of Acmaeopleura toriumii

In order to clarify that Acmaeopleura toriumii is not a burrowing species, a field experiment was conducted at the mud flat at Yamaguchi Prefecture in August 1997. Twenty-three A. toriumii were collected with a shovel and placed on the nearby sediment surface at low tide. Crabs were 
kept individually in polyvinylchloride pipes $(6 \mathrm{~cm}$ in diameter and $10 \mathrm{~cm}$ long). Each pipe was placed on the mud with one end to the mud surface with a crab and the other end covered with 1 $\mathrm{mm}$-meshed net. After 24 hours, presence or absence of the burrows and the crabs were checked.

So as to determine that Acmaeopleura toriumii is not surface dweller in mud sediment, field samplings were conducted at the mud flat at Yamaguchi Prefecture in August 1997. Surface sediment $(20 \times 20 \mathrm{~cm})$ with abundant Upogebia burrows was scooped with a shovel to a depth of $3 \mathrm{~cm}$, sieved and checked for the presence or absence of $A$. toriumii. The sediment samplings were conducted 100 times at both low and high tide.

\section{Results}

\section{Field collection}

More than 100 specimens of Acmaeopleura toriumii (carapace widths, $2.0-8.1 \mathrm{~mm}$ ) were collected from September 1994 to November 1995. In many cases burrows collapsed just after digging the sediment and I was not able to determine whether $A$. toriumii was associated with Upogebia burrows. In some cases, however, individuals of $A$. toriumii were observed associated with the Upogebia burrows (Fig. 1). Some individuals of $A$. toriumii were also sucked directly out of the burrows by a suction pump. In March 1995, four individuals of $A$. toriumii were found among egg masses of an ovigerous female of $U$. major. As for Acmaeopleura sp., 14 specimens (carapace width, $2.2-8.2 \mathrm{~mm}$ ) were collected. Eight individuals of Acmaeopleura sp. were found clinging to the abdomen of $U$. major and six were found from the sieved sediment.

\section{Observation in aquaria}

Specimens of Acmaeopleura toriumii stayed under pebbles or on the mud, and did not make burrows. The crab ate pieces of clam and fish, and also ate dead shrimp and exuvia of the shrimp. The crab sometimes used its chelipeds to scoop mud toward its mouth and its third maxillipeds for filter feeding. Animals of this species $(n>50)$ never clung to Upogebia major.

Every specimen of Acmaeopleura sp. $(n=10)$ that was placed in an aquarium with Upogebia major found a shrimp and clung to it; even the smallest specimen (carapace width $=2.2 \mathrm{~mm}$ ) behaved in this way. The crab usually clung to the ventral side of the first and second abdominal segments of the host shrimp, using the dactyls of the second, third, and sometimes fourth pereiopods as hooks; its head was facing toward the telson of the host (Fig. 2). In a few cases, the crab clung to the ventral side of the sixth abdominal segment. The host shrimp sometimes scraped the crab with its fifth pereiopod, but the crab was never observed to leave. The crab sometimes migrated to another host individual, though whether the crab was forced to leave by the host or the crab left for another reason was not determined.

Acmaeopleura sp. used its chelipeds to pick some material from the host body and carried it to the mouth. A few days after a crab had attached to a host, a small wound appeared on the abdomen of the host shrimp. The wound expanded daily, and in some cases the first pleopods of female hosts were lost (Fig. 3). Because the wounds reached to the epidermis of the shrimp ( $n=$ 14), I concluded that the crabs feed on the host tissue, as well as on surface debris. Of the 333 specimens of Upogebia major collected from September 1994 to May 1995, 43 specimens (12.9\%) had abdominal wounds like those produced by crabs in the laboratory.

When put into a vinyl tube containing $U$. major, every individual of Acmaeopleura toriumii ( $n=20,200$ observations) was soon detected by the shrimp, picked up, and cast out of the vinyl burrow. On the contrary, Acmaeopleura sp. succeeded to cling to the shrimp in more than half the observations ( $n=10,100$ observations). In 27 of 100 observations, Acmaeopleura sp. put into the tubes were found by $U$. major, picked up, and cast out of the vinyl burrow. In the other 73 cases, a crab stole up toward the host from behind and kept still under the abdomen and tried to cling to the host when the host moved. In 57 out of 73 cases, a crab scrambled up the second pleopods 


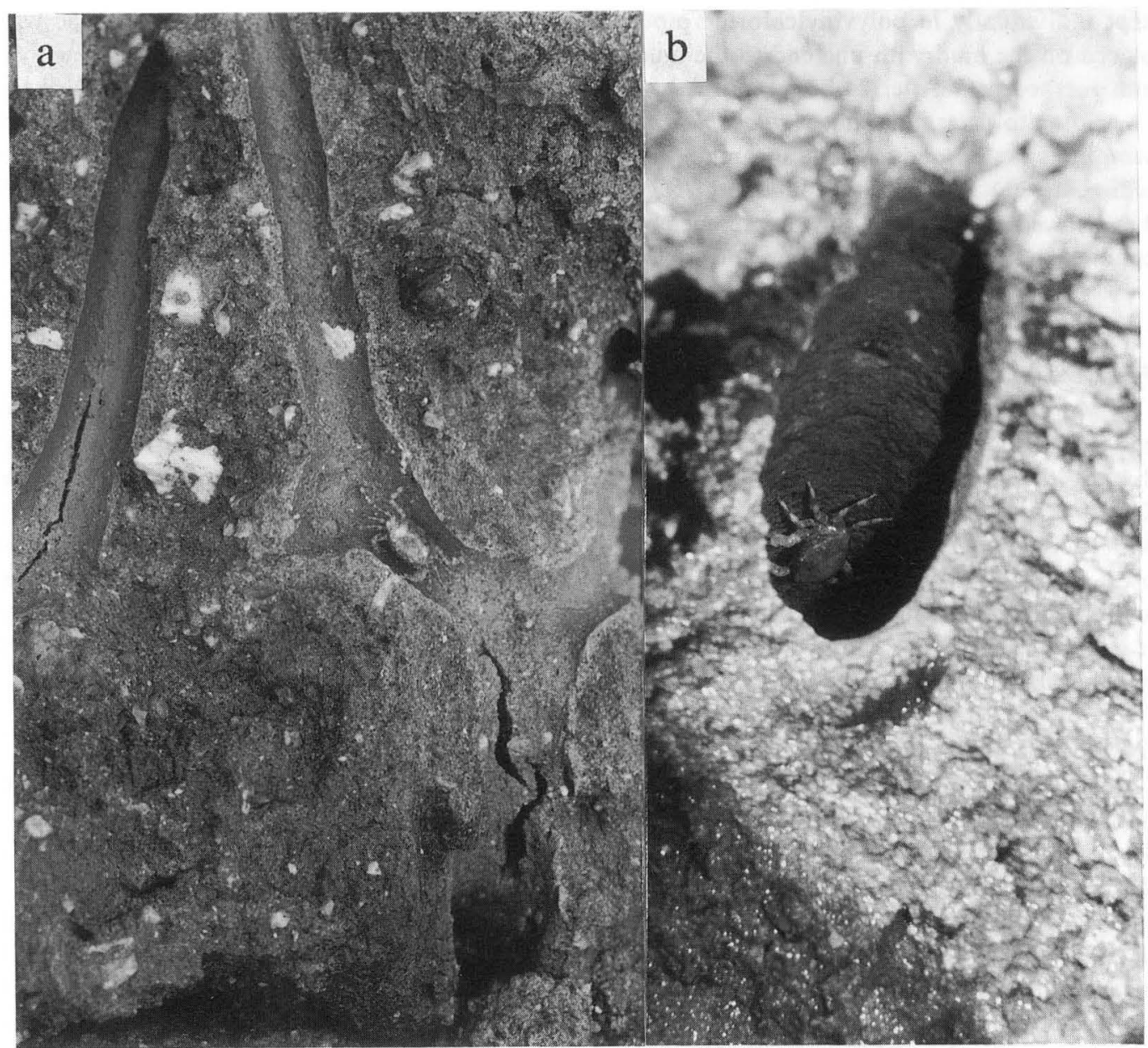

Fig. 1. Acmaeopleura toriumii in the burrows of Upogebia major. Substrate mud was dug carefully with a shovel and burrows of Upogebia were exposed. a: A female (carapace length=6.2 $\mathrm{mm}$ ). b: Another female (carapace length $=7.5 \mathrm{~mm}$ ).

or the fifth pereiopods of the host and were able to cling to the first and second abdominal segments. In other 9 cases a crab climbed the telson and clung to the sixth abdominal segment, and in the other 7 cases a crab failed to climb the host and was cast out of the burrow by the host.

Field experiment and distribution of Acmaeopleura toriumii

Twenty-four hours after 23 individuals of Acmaeopleura toriumii were placed on the mud surface, 19 were found buried in the mud surface, without making their own burrows. Fourteen of the 19 crabs were found at $0 \sim 1 \mathrm{~cm}$ depth; four at $1 \sim 2 \mathrm{~cm}$; one at $2 \sim 3 \mathrm{~cm}$. Four individuals were not found in the sediment. But in all the four cases, burrow entrances of Upogebia major were found on the sediment covered with polyvinylchloride pipes and missing crabs would have entered to the Upogebia burrows. As a result of surface sediment samplings, no individual of Acmaeopleura toriumii was found at low tide or high tide. 

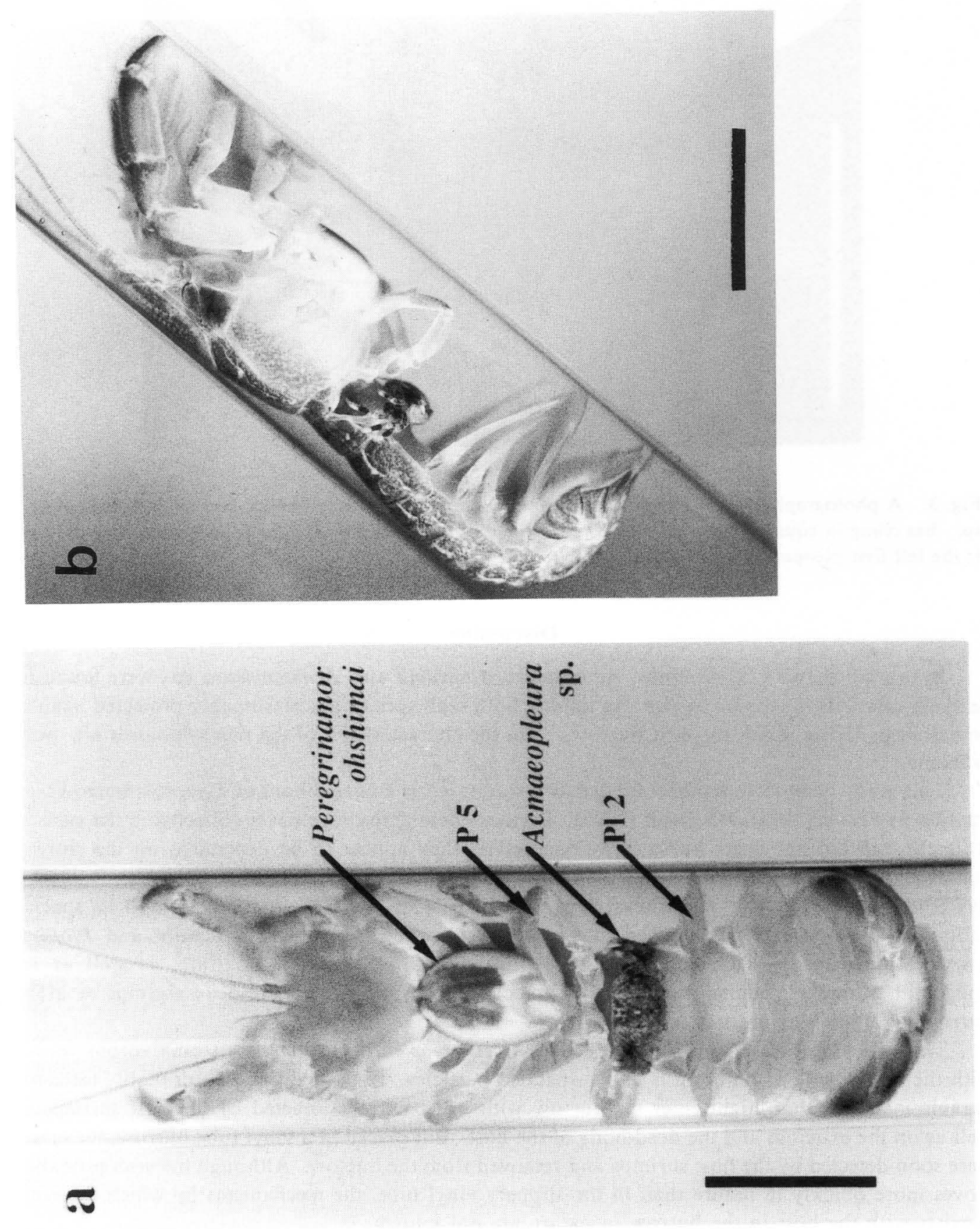

Fig. 2. A living male specimen of Acmaeopleura sp. clinging to the host Upogebia major (put in a glass tube for photographs). The host harbors the symbiotic bivalve Peregrinamor ohshimai as well. a: Dorsal view of the crab. b: Side view of the crab. P5; the fifth pereiopod of U. major, Pl2; the second pleopod of $U$. major. Scale bar $=10 \mathrm{~mm}$. 


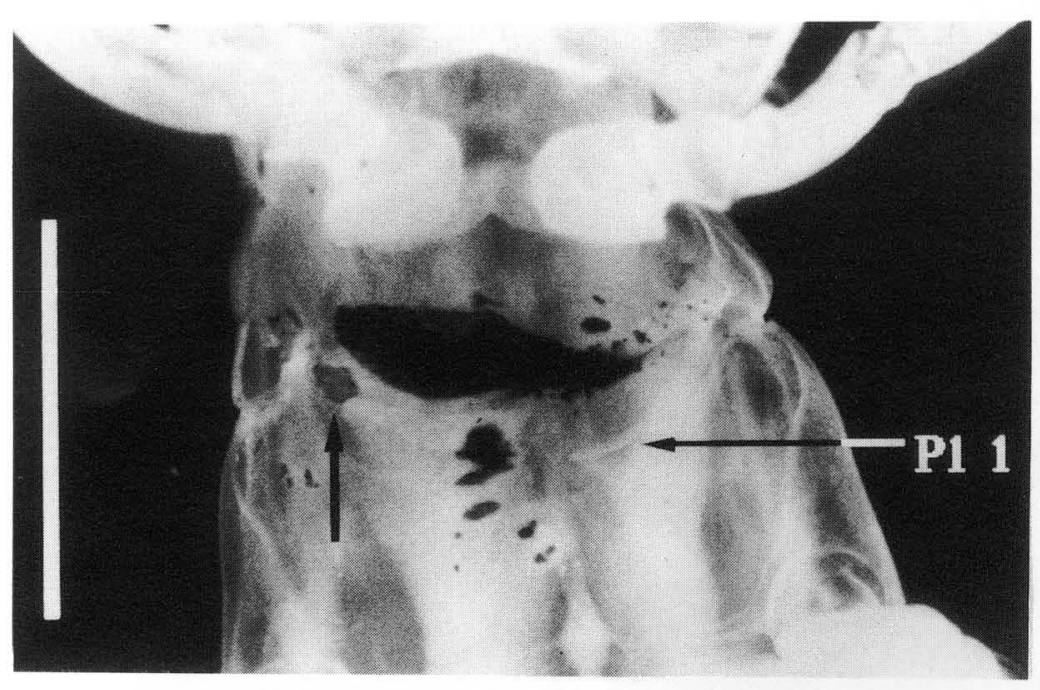

Fig. 3. A photograph of the wounded abdomen of a female host shrimp twenty days after Acmaeopleura sp. has clung in aquaria. See the right first pleopod of the shrimp lost by the crab feeding (arrow). Pl 1; the left first pleopod. Scale bar $=10 \mathrm{~mm}$.

\section{Discussion}

In this study two grapsid crabs, Acmaeopleura toriumii and Acmaeopleura sp., were found to be symbiotic with Upogebia major. In nature, both crab species are presumably protected against predators by living inside the host burrows. But the characteristics of the two symbioses are quite different.

This study demonstrated that Acmaeopleura toriumii is a co-habitant of Upogebia burrows, as implied by Davie (1992) and Sakai (2000). Because these crabs were never collected in the surface sediment and did not make burrows by themselves, they appear to be dependent on the shrimp burrows. Acmaeopleura toriumii had previously been found in a few localities other than Onagawa Bay (the type locality in the northeast Japan); the rarity of this crab might be due to its special habitat. MacGinitie (1935) showed that pinnotherid crabs, Scleroplax granulata and Pinnixa schmitti, were burrow commensals of an echiuroid and a callianassid shrimp, as well as an upogebiid shrimp. Whether $A$. toriumii is associated with other thalassinidean shrimps or other burrowing animals is under study.

The behavioral observations suggested that Acmaeopleura toriumii is an omnivorous feeder with the ability to feed on detritus and suspended particles. In nature, the crab probably feeds on organic materials that might enter the burrow with water currents created by the host shrimp, as well as on the exuvium and the dead body of the host. But placed in a vinyl tube burrow, the crabs were soon detected by the host shrimps and removed from the burrow. Although the crab probably moves more quickly in nature than in the slippery vinyl tube, the mechanisms by which the crab coexists with the host in the burrow in nature are not known.

The life of Acmaeopleura sp. seems to depend on the association with Upogebia. The crabs were collected clinging to the abdomen of the host Upogebia major and they always clung to the host in aquaria. Crabs that were collected from sediments containing Upogebia burrows had probably been detached from the body of their host when the sediments were dug and sieved. Although housekeeping activities of Upogebia shrimp are high, Acmaeopleura sp. will flee from them clinging directly to the shrimp body. Even if detached from a host, Acmaeopleura sp. would 
migrate to a nearby burrow and cling to another host individual.

Crabs in aquaria were thought to feed on tissue from the ventral surface of the abdomen of the host. This feeding habit of the crab was not an artifact caused by their maintenance in aquaria, considering about $13 \%$ of the collected specimens of $U$. major in the field had an injured abdomen attributable to the crab. But whether the living host tissue is the primary diet was uncertain, because the crab was thought to feed on debris on the host body as well. Feeding experiments and gut content analyses of the two crabs are under study.

The second to fifth pleopods of Upogebia shrimps are foliaceous and create the water currents necessary for feeding and ventilation. The first pleopods of the male are absent, and those of the female are simple and small, carrying eggs in the breeding season. There is, in both sexes, a large space between the fifth pereiopods and the second pleopods. Usually the crab stays in that space (Fig. 2), a convenient location for clinging to its host: First, the crab is not pressed to the burrow wall when the host shrimp moves. Second, the crab is not disturbed by the beating pleopods of the host. Third, the host cannot use the cleaning legs (i.e. the fifth pereiopods) effectively to scrape off the crab, which is lying just behind the legs. Fourth, the ventral abdominal cuticle of the host shrimp is not hard, like the exoskeleton of the cephalothorax and dorsal abdomen, so the crab can cling and feed more easily. Finally, the foliaceous pleopods of the host create an upwelling near the base of the second pleopods that brings fresh water and detrital matter to the crab. Such an upwelling was observed near the bases of the first foliaceous pleopods of a stomatopod, Oratosquilla oratoria, to which a galeommatid bivalve Pseudopythina subsinuata was attached (Morton, 1972). The space between the fifth pereiopods and the second pleopods of Upogebia pugettensis, a species in the eastern Pacific, is utilized by the bivalve Pseudopythina rugifera and P. compressa, and the bopyrid isopods Phyllodurus abdominalis, but not by crabs (MacGinitie, 1935).

Ghani and Tirmizi (1991) reported that two females of Acmaeopleura crab were collected attached to the bases of thoracic appendages of Upogebia quaddusiae in the Arabian Sea. The reported habit of the crab is interesting but rather curious in that the crab does not appear to locate in the space on the first and second abdominal segments which is used by Acmaeopleura sp., bopyrid isopods, and bivalves. The ventral side of the cephalothorax of Upogebia shrimps is usually free of other animals, except for the highly specialized, symbiotic bivalves Peregrinamor ohshimai and $P$. gastrochaenans, that attach there by its byssus and uses the anterior inhalant siphon to pilfer the suspended matter captured by the setal basket of the hosts (Kato and Itani, 1995, 2000). In the absence of special feeding habits, the ventral cephalothorax of shrimps would seem to be inhospitable for crabs. Behavioral and systematic studies of the Acmaeopleura crabs in the Arabian Sea are required.

The case of a decapod ectosymbiont on another decapod is extremely rare (Ross, 1983). Common hosts of decapod symbionts are sedentary or less mobile animals, such as cnidarians, mollscs, annelids and echinoderms (Ross, 1983). Exceptional cases are some species of porcellanid crabs which live inside the shells of live gastropods and hermit crabs (Telford and Daxboeck, 1978; Werding, 1983), and the alpheid shrimp Aretopsis amabilis which lives in the hermit crab shell and eats the faeces of the host (Bruce, 1969; Kamezaki and Kamezaki, 1986). In both cases, the decapod symbionts will be considered as shell co-habitants and may be comparable to burrow co-habiting shrimps and crabs. Thus, Acmaeopleura sp. - Upogebia symbiosis would be a novel case of symbiotic relationship in decapod crustaceans in that the crab lives ectoparasitic with a shrimp. Acmaeopleura sp. - Upogebia symbiosis could be realized by the fact that upogebiid shrimps are rather motionless animals once having established their burrows and the fact that grapsid crabs are quick in their movement. Further investigations must examine morphological and ecological differences between Acmaeopleura crabs, and the relative costs/benefits and the specificity of the symbiotic relationships. 


\section{Acknowledgements}

I express my gratitude to Y. Shirayama, E. Harada, and M. Kato who read the manuscript and supported all aspects of this study. I especially thank A. Taki, M. Takeda, K. Wada, and P. Davie for providing information about the crabs; S. Nishimura and R. Asai for technical assistance; M. Imafuku, Y. Fukui, and K. Iwasaki for helpful comments on this study; and K. Yoshimura, T. Inoue, and Y. Itani for field assistance. Thanks are also due to $A$. Mori and $T$. Uchino who provided valuable literature, and all the other members of the Seto Marine Biological Laboratory and the Laboratory of Animal Ecology of Kyoto University who helped me with the experiments and observations. I would like to thank M. J. Greenberg and anonymous reviewers for constructive comments on the earlier version of the manuscript. This study was partly supported by a Grant-in-Aid for Scientific Research from the Ministry of Education, Culture, Sports, Science and Technology, Japan, and a JSPS Fellowship for Young Scientists.

\section{References}

Brenchley, G. A. 1981. Disturbance and community structure: an experimental study of bioturbation in marine soft-bottom environments. Journal of Marine Research, 39, 767-790.

Bruce, A. J. 1969. Aretopsis amabilis De Man, an alpheid shrimp commensal of pagurid crabs in the Seychelle Islands. Journal of the Marine Biological Association of India, 11, 175-181.

Coelho, V. R., Williams, A. B. and Rodrigues, S. D. A. 2000. Trophic strategies and functional morphology of feeding appendages, with emphasis on setae of Upogebia omissa and Pomatogebia operculata (Decapoda: Thalassinidea: Upogebiidae). Zoological Journal of the Linnean Society, 130, 567-602.

Dales, R. P. 1957. Commensalism. In, Hedgpeth, J. W. (ed.) Treatise on Marine Ecology and Paleoecology, Vol. 1, Memoir 67, Geological Society of America, New York, pp. 391-412.

Davie, P. J. F. 1992. A new species and new records of intertidal crabs (Crustacea: Brachyura) from Hong Kong. In, Morton, B. (ed.) The Marine Flora and Fauna of Hong Kong and Southern China III, Hong Kong University Press, Hong Kong, pp. 345-359.

Dworschak, P. C. 1987. Feeding behaviour of Upogebia pusilla and Callianassa tyrrhena (Crustacea, Decapoda, Thalassinidea). Investigación Pesquera, 51 (Supl. 1), 421-429.

Ghani, N. and Tirmizi, N. M. 1991. Acmaeopleura balssi Shen, 1932: A grapsid genus and species hitherto unknown from the northern Arabian Sea (Decapoda, Brachyura). Crustaceana, 61, 93-95.

Griffis, R. B. and Suchanek, T. H. 1991. A model of burrow architecture and trophic modes in thalassinidean shrimp (Decapoda: Thalassinidea). Marine Ecology Progress Series, 79, 171-183.

Grossman, G. D. 1979. Symbiotic burrow-occupying behavior in the bay goby, Lepidogobius lepidus. California Fish and Game, 65, 122-124.

Kamezaki, N. and Kamezaki, Y. 1986. On the ecology of alpheid shrimp Aretopsis amabilis De Man. Nanki Seibutu, 28, 11-15. [in Japanese with English summary]

Kato, M. and Itani, G. 1995. Commensalism of a bivalve, Peregrinamor ohshimai, with a thalassinidean burrowing shrimp, Upogebia major. Journal of the Marine Biological Association of the United Kingdom, 75, 941-947.

Kato, M. and Itani, G. 2000. Peregrinamor gastrochaenans (Bivalvia: Mollusca), a new species symbiotic with the thalassinidean shrimp Upogebia carinicauda (Decapoda: Crustacea). Species Diversity, 5, 309-316.

MacGinitie, G. E. 1930. The natural history of the mud shrimp Upogebia pugettensis (Dana). Annals and Magazine of Natural History, Series 10, 6, 36-44.

MacGinitie, G. E. 1935. Ecological aspects of a California marine estuary. American Midland Naturalist, $16,629-765$.

Manning, R. B. 1975. Two methods for collecting decapods in shallow water. Crustaceana, 29, 317-319.

Manning, R. B. and Felder, D. L. 1989. The Pinnixa cristata complex in the Western Atlantic, with a description of two new species (Crustacea: Decapoda: Pinnotheridae). Smithsonian Contributions to Zoology, 473, 1-26.

Morton, B. 1972. Some aspects of the functional morphology and biology of Pseudopythina subsinuata (Bivalvia: Leptonacea) commensal on stomatopod crustaceans. Journal of Zoology, London, 166, 79- 
96.

Nickell, L. A. and Atkinson, R. J. A. 1995. Functional morphology of burrows and trophic modes of three thalassinidean shrimp species, and a new approach to the classification of thalassinidean burrow morphology. Marine Ecology Progress Series, 128, 181-197.

Norman, A. M. 1891. Lepton squamosum (Montagu), a commensal. Annals and Magazine of Natural History, Series 6, 7, 276-278.

Poore, G. C. B. 1994. A phylogeny of the families of Thalassinidea (Crustacea: Decapoda) with keys to families and genera. Memoirs of the Museum of Victoria, 54, 79-120.

Posey, M. H., Dumbauld, B. R. and Armstrong, D. A. 1991. Effects of a burrowing mud shrimp, Upogebia pugettensis (Dana), on abundances of macro-infauna. Journal of Experimental Marine Biology and Ecology, 148, 283-294.

Ríos, R. and Carvacho, A. 1983. Caridean shrimps of the gulf of California. III. Leptalpheus mexicanus, new species (Crustacea, Decapoda, Alpheidae). Journal of Crustacean Biology, 3, 306-313.

Ross, D. M. 1983. Symbiotic Relations. In, Vernberg, F. J. and Vernberg, W. B. (eds.) The Biology of Crustacea, Vol. 7, Academic Press, New York, pp. 163-212.

Sakai, K. 2000. On the occurrence of three species of crabs on Shikoku Island, Japan, and a new species, Pinnotheres taichungae nov. spec., from Taiwan (Decapoda, Brachyura). Crustaceana, 73, 1152-1162.

Sakai, T. 1976. Crabs of Japan and the Adjacent Seas. Kodansha, Tokyo, xxix +773 pp. (English part), 461 pp. (Japanese Part), 16 pp. +251 plates.

Stevcić, Z., Castro, P. and Gore, R. 1988. Re-establishment of the family Eumedonidae Dana, 1853 (Crustacea: Brachyura). Journal of Natural History, 22, 1301-1324.

Telford, M. and Daxboeck, C. 1978. Porcellana sayana Leach (Crustacea: Anomura) symbiotic with Strombus gigas (Linnaeus) (Gastropoda: Strombidae) and with three species of hermit crabs (Anomura: Diogenidae) in Barbados. Bulletin of Marine Science, 28, 202-205.

Vandenspiegel, D., Ovaere, A. and Massin, Cl. 1992. On the association between the crab Hapalonotus reticulatus (Crustacea, Brachyura, Eumedonidae) and the sea cucumber Holothuria (Metriatyla) scabra (Echinodermata, Holothuridae). Bulletion de l'Institut Royal des Sciences Naturelles de Belgique, Biologie, 62, 167-177.

Weinbauer, G., Nussbaumer, V. and Patzner, R. A. 1982. Studies on the relationship between Inachus phalangium Fabricius (Maiidae) and Anemonia sulcata Pennant in their natural environment. P. S. Z. N. I: Marine Ecology, 3, 143-150.

Werding, B. 1983. Kommesalische Porzellaniden aus der Karibik (Decapoda, Anomura). Crustaceana, $45,1-14$. 


\section{Instruction to Authors}

The Publications of the Seto Marine Biological Laboratory (referred as the Publications hereafter) are issued regularly by the Seto Marine Biological Laboratory of Kyoto University. The publications aim to contribute to the progress of marine biology and related sciences by publishing the scientific papers regarding organisms of mainly Japanese and Indo-Pacific waters. Papers related to the natural history, such as taxonomy, morphology, and evolutionary biology are the most suitable, and particularly those recording works done at the Laboratory are favorable.

Submitted papers must not have been published nor be under consideration for publishing elsewhere in any languages. The submitted papers will be reviewed at least by two referees, and only those papers evaluated their scientific findings are worth for publication will be accepted. Such papers that is judged not paid sufficient attention to the wildlife conservation and the humane treatment of animals will be rejected.

Manuscript should be sent to the editor in chief (Yoshihisa Shirayama) of the Publications at the following address:

Seto Marine Biological Laboratory,

459 Shirahama, Wakayama Pref., 649-2211, Japan

Authors are requested to read the following instruction carefully, and prepare their manuscript properly. Poor attention to the instruction may cause unnecessary delay of the processing of papers.

Manuscripts should be prepared in English as concisely as possible. Those authors whose native language is not English should ask native English speaker to correct language usage before submitting the manuscript. Original and two copies of the manuscript consisting of text, tables and the illustrations should be provided.

Text:

The text should be printed in double spaced manner on one side of A4 size paper leaving margins of more than $3 \mathrm{~cm}$ in width all around, All sheets should be numbered consecutively, and the name of the senior author should be given on the upper right corner.

The first page of the text should include the title of the paper, information of author(s) (name, affiliation, and corresponding address inclusive of e-mail address of all authors and telephone and fax numbers of the representative author), the running title (not more than 50 characters), and key words (not more than 10 items).

The second page should include only the abstract of the paper (less than 300 words), expressing concisely the hypothesis, the approach the author(s) adopted, the results, and the conclusion.

The main body of the text consisting of introduction, materials and methods, results, discussion, acknowledgments, reference and so on, should be prepared from page 3. The papers listed in the reference section should be referred as Tokioka $(1960,1961$ a) or (Harada, 1995; Harada et al., 1992; Harada and Fuse, 1994).

The reference should list all the papers mentioned in the text alphabetically in the following manner.

Referring papers published in journals:

Shirayama, Y. 1984a. The abundance of deep-sea meiobenthos in the Western Pacific in relation to environmental factors. Oceanologica Acta, 7, 113-121.

Shirayama, Y, 1984b. Vertical distribution of meiobenthos in the sediment profile in bathyal, abyssal and hadal deep-sea systems of the Western Pacific. Oceanologica Acta, 7, 123-129.

Shirayama, Y. and Horikoshi, M. 1989. Comparison of the benthic size structure between sublittoral, 
upper-slope and deep seas of the Western Pacific. Internationale Revue der gesamten Hydrobiologie, $74,1-13$.

(It should be noticed that the title of journals should not be abbreviated.)

Referring papers published in books:

Shirayama, Y. 1995. Current status of deep-sea biology in relation to the $\mathrm{CO}_{2}$ disposal. In, Handa, N. and Ohsumi, T. (eds.) Direct Ocean Disposal of Carbon Dioxide, Terra Scientific Publishing Company, Tokyo, pp. 253-264.

Referring a book as a whole:

Gage, J. D. and Tyler, P. A. 1991. Deep-Sea Biology. Cambridge University Press, Cambridge, $504 \mathrm{pp}$.

Tables:

The tables should be provided in the shape ready to reproduce. Each table should be printed on a separate sheet of paper using a font "Times new roman" or related one. The large table that can not be printed in 2 pages is not acceptable.

\section{Figures:}

Illustrations should be prepared in a size of not smaller than B5 and not larger than A3. They should fit to the shape of the page, that is $14 \mathrm{~cm}$ wide by $20 \mathrm{~cm}$ height at maximum. Authors are requested to pay the most careful attention to the thickness of lines, the size of letters and the spacing of drawings. Photographs should be printed in a high contrast tone. Manuscripts inclusive of figures will not be returned to the authors unless they requested. The cost for printing the color plates must be covered by the author.

\section{Proofs:}

The first galley proof will be sent to the senior author. The author should return it to the editor within 3 days after the receipt. Only corrections of typographic errors are allowed at this stage.

\section{Reprints:}

The publications provide 50 reprints to the senior author free of charge. The author can order additional reprints when the author returns the galley proof to the editor.

\section{Page charge:}

The pubilications do not set the maximal length of each article, and will not bill the page charge for the regular black-ink printing. However, the cost for printing color plates should be covered by the author(s).

\section{Computer files:}

To save the cost for publishing and to reduce typographic errors, the publications request the author to provide computer files to the editorial board when the manuscript is accepted for publishing. Use of the 3.5 inch 2DD or 2HD floppy disk (preferably formatted by MS-DOS) that records plain text files and clearly marked the author name and the title of the paper is requested. Use of electric mail may be also acceptable. If the author used a word processor for preparing the manuscript, the binary file used by the program is also requested to be provided, and information for the word processor program must be provided. It is not recommended to provide data files in stead of line drawings and photographs. 